\title{
The precautionary principle in maritime affairs
}

\author{
Runyu Wang
}

Received: 18 January 2011 / Accepted: 28 April 2011 /Published online: 17 May 2011

(C) World Maritime University 2011

\begin{abstract}
Since the 1980s, the precautionary principle has been drawing more and more international attention. This became particularly clear during the series of Conferences on the Protection of the North Sea, which addressed marine environmental protection, and initiated the application of the principle into maritime affairs. Although a unified concept of the precautionary principle is lacking, some typical formulations have been concluded in regional treaties and international documents, and components of the principle can be summarised (Part I and Part II). The precautionary principle has been adopted by international documents involving different fields of law of the sea, and been addressed by international courts and tribunals (Part III). While the precautionary principle is still not part of customary international law (Part IV), its increasing level of worldwide acceptance suggests that it will become a customary international law in the future.
\end{abstract}

Keywords Maritime protection · Precautionary principle $\cdot$ Precautionary approach · International law · UN Fish Stocks Agreement

\section{Development of the precautionary principle}

Although a few scholars indicate that the spirit of the precautionary principle can be traced back to the 1930s (Sands 2003), it is inarguable that the principle formally emerged in international treaties in the 1980, whereas the concept of Vorsorgeprin-

This article has been prepared for a seminar of the International Max Planck Research School for Maritime Affairs (IMPRS), 2010, Hamburg.

\footnotetext{
R. Wang $(\bowtie)$

International Max Planck Research School for Maritime Affairs, Mittelweg 187, 20148 Hamburg, Germany

e-mail: wang@mpipriv.de
} 
zip, which literally translates the precautionary principle, had already been used in a number of German laws in the 1970s. ${ }^{1}$ The precautionary principle was first explicitly stipulated by the Vienna Convention for the Protection of the Ozone Layer which was adopted in 1985 to protect human health and the environment against the adverse affects of ozone depletion. ${ }^{2}$ Two years later, in 1987, it was reiterated in the Montreal Protocol on Substances that Deplete the Ozone Layer. ${ }^{3}$ The attention given to ozone depletion compelled international society to support the precautionary principle, leading to its increasingly frequent inclusion in international environmental protection documents.

In the field of maritime affairs, the precautionary principle, as a measure to protect the marine environment, has featured at the series of Conferences on the Protection of the North $\mathrm{Sea}^{4}$ since the first conference in 1984. From then on, the principle, or its underlying rationale, has been incorporated into numerous international documents, including the 1992 Rio Declaration, 1992 Convention on the Protection of the Marine Environment of the North-East Atlantic (OSPAR Convention), 1992 Convention on the Protection of the Marine Environment of the Baltic Sea (Helsinki Convention), the 1995 Agreement for the Implementation of the United Nations Conventions on the Law of the Sea of 10 December 1982 relating to the Conservation and Management of Straddling Fish Stocks and Highly Migratory Fish Stocks (UN Fish Stocks Agreement), 1996 London Protocol to the Convention on the Prevention of Pollution by Dumping of Wastes, 2000 Cartagena Protocol on Biosafety, and 2001 Stockholm Convention on Persistent Organic Pollutants. The general application of the principle as the basis for sustainable development is beyond doubt, especially bridging the gap between preservation of the environment and ecosystems and scientific uncertainty surrounding the potential damage arising from the exercise of activities.

The lack of uniform understanding of the precautionary principle has resulted in a number of various formulations of the principle in different international documents. For example, the OSPAR is one of the strictest rules of precautionary measures. ${ }^{5}$

\footnotetext{
${ }^{1}$ Cameron, James and Abouchar, Juli, "The Precautionary Principle: A Fundamental Principle of Law and Policy for the Protection of the Global Environment", (1991) 14 Boston College International and Comparative Law Review 1, p. 6; Gardiner, Stephen M., "A Core Precautionary Principle”, (2006) 14 The Journal of Political Philosophy 33, pp. 34-35; Sand, supra note 1. Such as: Bundesimmissionsschutzgesetz (1974), Article 5, §1, No.2; Atomgesetz, Article 7, § 2, No. 3; and Gesetz über die Umweltverträglichkeitsprüfung.

${ }^{2}$ Vienna Convention for the Protection of Ozone Layer, 1985, Preamble: "Mindful also of the precautionary measures for the protection of the ozone layer which have already been taken at the national and international levels". http://www.unep.org/ozone/viennaconvention2002.pdf

${ }^{3}$ Montreal Protocol on Substances that Deplete Ozone Layer, 1987, Preamble: "[T]o protect the ozone layer by taking precautionary measures to control equitably total global emissions of substances that deplete it." http://www.unep.org/ozone/pdfs/montreal-protocol2000.pdf

${ }^{4}$ The conference was composed of Ministers responsible for the protection of the North Sea of the Governments of Belgium, Denmark, France, the Federal republic of Germany, the Netherlands, Norway, Sweden, the UK, as well as the Member of the Commission of the European Communities.

5 Article 2 (2) (a) of the OSPAR reads: "The Contracting Parties shall apply the precautionary principle, by virtue of which preventive measures are to be taken when there are reasonable grounds for concern that substances or energy introduced, directly or indirectly, into the marine environment may bring about hazards to human health, harm living resources and marine ecosystems, damage amenities or interfere with other legitimate uses of the sea, even when there is no conclusive evidence of a causal relationship between the inputs and the effects."
} 
In contrast to other formulations of the precautionary approach, it combines preventive and precautionary measures and lowers the level of scientific evidence required. If there is reason to presume that harm might be caused, the precautionary principle should be adopted. It does not emphasise, as previous international documents had, that the damage should be "serious and irreversible", leading to criticism of overregulation and difficulty in compliance in practice (Atapattu 2006). However, the Rio Declaration, as a cornerstone of the principle, provides the most widely accepted formulation of the principle (Hewison 1996; Manson et al. 2002), and raises the threshold level of damage. ${ }^{6}$ It emphasises that a high level of threatened damage, while also providing that preventative measures should be cost-effective. Comparing these two international documents, the former is a regional convention, whose parities are developed states with high living standards, thus making more feasible the institution of a low threshold for the precautionary principle in order to better protect regional environment; the latter is a non-binding global declaration, "with the goal of establishing a new and equitable global partnership" to "protect the integrity of the global environmental and developmental system". This broader scope requires a broader approach, and the agreement seeks to balance the different interests of various economic and social groups from all over the world. These interests make a balance between environmental protection and development more complex, thereby requiring that the threshold for the precautionary principle be set higher to facilitate its acceptance and implementation in the face of criticism that the principle would limit human development (Garcia 1994; Burke 1993). After the wide acceptance of the Rio Declaration, its formulation of the precautionary principle has been adopted by other international documents, ${ }^{7}$ and the principle has since become an intrinsic part of international environmental law. ${ }^{8}$ Principle 15 of the Rio Declaration covers not only global environmental problems but also any kind of environmental damage within national territorial boundaries, despite its nonbinding status. ${ }^{9}$ Proponents of the precautionary principle believe that it provides the best opportunity to reduce uncertainty about environmental cause and effect, ${ }^{10}$ and this development has had broad-reaching effects, not only for international environmental law (Nollkaemper 1991) but also for the law of the sea, such as fishery law.

\footnotetext{
${ }^{6}$ Principle 15 of the Rio Declaration on Environment and Development, The United Nations Conference on Environment and Development, Rio de Janeiro, 1992: "In order to protect the environment, the precautionary approach shall be widely applied by States according to their capabilities. Where there are threats of serious or irreversible damage, lack of full scientific certainty shall not be used as a reason for postponing cost-effective measures to prevent environmental degradation."

${ }^{7}$ Such as Cartagena Protocol on Biosafety to the Convention on Biological Diversity, 2000, its objective, which declared in Article 1, is "in accordance with the precautionary approach contained in Principle 15 of the Rio Declaration on Environment and Development".

${ }^{8}$ Wolfrum, Rüdiger, "Precautionary Principle", in Beurier, Jean-Pierre, Kiss, Alexander, and Mahmoudi, Said (Eds.), New Technologies and Law of the Marine Environment, (Kluwer International Law, 2000), p. 203.

${ }^{9}$ Atapattu, supra note 7, p. 204.

${ }^{10}$ Goldstein, Bernard D., "The Precautionary Principle and Scientific Research are not Antithetical", (1999) 107 Environmental Health Perspectives A594, p. A594.
} 


\section{Concept and components of the precautionary principle}

\subsection{Precautionary approach and precautionary principle}

Prior to commencing detailed analyses, it is necessary to briefly introduce two terms: "precautionary approach" and "precautionary principle", which are both used in official documents. The Oxford English Dictionary defines the term "approach" as a way of considering or handling something, especially a problem, and defines the term "principle" as a source of action or a general law or rule adopted or professed as a guide to action (Hey 1992). Literally, "precautionary approach" refers to a method, which normally takes socio-economic conditions into consideration, such as calling for "cost-effectiveness" and recognising the capabilities of different states. The "precautionary principle", as a general law, indicates that parties have a responsibility to obey the principle. Therefore, while a failure to follow the "precautionary approach" may not give rise to legal consequences, violation of the "precautionary principle" is illegal. When measures are adopted to prevent potential threats, the "approach" and "principle" may express different degrees of impact.

However, in practice, the two terms are "rather arbitrary" because there is no clear explanation outlining the weakness of the "approach" and the strictness of the "principle" (Marr 2003). In addition, the "approach" has received sufficiently broad acceptance in international treaties and national legislations, thereby attaining mandatory obligation for actors. It is not surprising that the legal status of the "approach" has changed into a principle of law, becoming a general law adopted as a guide for developing future international law. Based on this reasoning, it could be concluded that there is nothing fundamentally distinguishing these two terms when they are used in most international treaties and national laws. This article uses the appellation "precautionary principle" only, except for when comparing specific international and national documents.

\subsection{Concept of the precautionary principle}

It is hard to find a unified definition of the precautionary principle in a globally endorsed international convention; however, the spirit of the principle has been found in a number of global and regional international instruments. In addition to those instruments already mentioned, some other international instruments also indicate the application of the precautionary principle, such as the International Convention for the Prevention of Pollution from Ships, Article 2(2); the Convention on the Protection of Transboundary Watercourses and International Lakes, Article 2 (a); the Stockholm Convention on Persistent Organic Pollutants, the Preamble and Article 1; and the Convention on the Regulation of Antarctic Mineral Resource Activities, Article 4(4). ${ }^{11}$ Although the precautionary principle originated in the field of environmental protection, after decades of evolution, it has been broadly accepted in other fields of the law of the sea. It is a huge triumph for the principle that it is

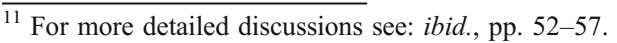


now applied to international and European fisheries management, including the UN Fish Stocks Agreement.

There are two successful examples of the application of the precautionary principle in regional conventions, which are worth noting: the Helsinki Convention ${ }^{12}$ and the OSPAR Convention. ${ }^{13}$ Both of these conventions are aimed at protecting the marine environment, including preventing and eliminating pollution, protecting human health, and ensuring healthy marine ecosystems in their respective marine areas, the Baltic Sea and the Northeast Atlantic. These two conventions treat the precautionary principle as fundamental, using similar language to articulate their aims. They require their contracting parties to apply the precautionary principle, i.e. take preventive measures when there are reasonable grounds to assume that substances or energy introduced into the marine environment may cause "hazards to human health, harm living resources and marine ecosystems, damage amenities or interfere with other legitimate uses of the sea, even when there is no conclusive evidence of a causal relationship between the inputs and the effects". 14

In the Helsinki Convention and the OSPAR Convention, the precautionary principle is a legally binding obligation for all parties, and is also a fundamental element of the Best Environmental Practice (BEP) and Best Available Technology

\footnotetext{
12 The Helsinki Convention entered into force on 17 January 2000. The 1974 Helsinki Convention for the Protection of the Marine Environment of the Baltic Sea Area was the first regional treaty to address all the sources of marine pollution and deeply influenced the formulation of the marine pollution provision of the United Nations Convention on the Law of the Sea. Political changes and development in international environmental and maritime law led to a new and more comprehensive convention being signed in 1992 by all the states bordering the Baltic Sea, and the European Community. The 1992 Helsinki Convention covers the whole of the Baltic Sea area, including not only the sea water and the seabed but also inland waters (Article 4 paragraph 2). Its purpose is to assure "the ecological restoration of the Baltic Sea, the possibility of self-regeneration of the marine environment and preservation of its ecological balance" (The Preamble). Therefore, besides controlling marine pollution, the convention also applies to the protection of living resources and other forms of marine life (Article 4 paragraph 1), the conservation of natural habitats and biological diversity and to the protection of ecological processes within the Baltic Sea Area (Article 15). More information see: Birnie, Patricia, Boyle, Alan, and Redgwell, Catherine, International Law and the Environment, $3^{\text {rd }}$ Edition, Oxford University Press 2009, p. 395; and the Helsinki Commission website: http://www.helcom.fi/Convention/en_GB/convention/

${ }^{13}$ Since the late $1960 \mathrm{~s}$, it had been recognised that it was very important to encourage international cooperation to combat marine pollution in the North East Atlantic. In 1972, the Convention for the Prevention of Marine Pollution by Dumping from Ships and Aircraft (Oslo Convention) was signed, which entered into force in 1974, and which underlined the need to control unlimited deliberate dumping of industrial waste into the sea. At the same time, it seemed necessary to conclude another convention dealing with the prevention of marine pollution resulting from the discharge of dangerous substances from land-based sources, watercourses or pipelines. Thus the Convention for the Prevention of Marine Pollution from Land-Based Sources (Paris Convention) was signed in 1974 and entered into force in 1978. After these two Convention were established, the Oslo Commissions and the Paris Commission was set up to administer their respective conventions. At the 1992 meeting of these Commissions, a new Convention, the OSPAR Convention, was adopted together with a Final declaration of the Ministerial Meeting of the Oslo and Paris Commissions and the Action Plan for the Oslo and Paris Commissions. It entered into force on 25 March 1998. The OSPAR Convention replaces and updates the Oslo Convention and the Paris Convention managing pollution of the sea from land-based and offshore sources and dumping. For more details see: OSPAR Commission website: http://www.ospar.org/welcome.asp?menu=0

${ }^{14}$ Article 3, paragraph 2, the 1992 Helsinki Convention, and supra note 6.
} 
(BAT) guidelines. ${ }^{15}$ Moreover, it is an active and positive obligation for contracting parties to take immediate measures to protect the marine environment even where there is lack of full scientific evidence (de La Fayette 1999). In other words, the contracting parties must apply the precautionary principle before real environmental harm occurs. ${ }^{16}$ Furthermore, the scope of the precautionary principle has been extended, to apply beyond pollution of the marine environment caused by introduction of substances and/or energy, to encompass all human activities which degrade the marine environment by other means and which might cause damage to biodiversity and marine ecosystems. Additionally, the threshold for applying the principle is much lower than preceding standards, and does away with the need for "serious or irreversible damage" to as a trigger for the application of the principle. ${ }^{17}$ It is difficult to evaluate whether the harm is serious or irreversible if there is a lack of scientific certainty evident; thus, the low threshold approach embodies the essential spirit of the principle-precaution. ${ }^{18}$ However, problems might arise when considering the term "reasonable grounds for concerns" or "reason to assume", which is open to interpretation and explanation by contracting parties according to their interests (Hey et al. 1992). Finally, unlike Principle 15 of the Rio Declaration, there is no requirement for precautionary measures to be "cost-effective". Thus, it should be treated as an independent principle when applied to pollution control. ${ }^{19}$ To summarise, the formulation of the precautionary principle in these two conventions established explicit obligations, a broadened scope of application, lower thresholds and few limitations. Through these applications, the principle is transforming from a vague aspiration for environmental protection into a substantial management instrument for a wide range of human activities.

Despite this, there is neither a uniform understanding of the meaning of the precautionary principle nor a set of criteria for its execution. However, some consistency has arisen; in a well-known definition, the precautionary principle has come to be described as:

When an activity raises threats of harm to human health or the environment, precautionary measures should be taken even if some cause and effect relationships are not fully established scientifically. ${ }^{20}$

\footnotetext{
${ }^{15}$ To prevent and eliminate pollution, the two conventions regulate that their parties shall adopt programmes and measures which take full account of the use of the latest technological developments and practices designed, and shall promote the use of the BEP and BAT. The BEP means the application of the most appropriate combination of measures; and the BAT refers to the latest stage of development of processes, of facilities or of methods of operation which indicate the practical suitability of a particular measure for limiting discharges. Article 3, paragraph 3 in connection with Annex II Regulation 2 and Regulation 3, the 1992 Helsinki Convention; and Article 2, paragraph 3 (b) in connection with Appendix 1.

${ }_{17}$ Article 2 paragraph 1, the Helsinki Convention; and the Article 1, paragraph d, the OSPAR Convention.

${ }^{17}$ Supra note 9.

18 de La Fayette, supra note 23, p. 255.

19 de La Fayette, supra note 23, p. 255; and Marr, supra note 17, p.61.

${ }^{20}$ Wingspread Statement on the Precautionary Principle, the Wingspread Conference Center, Racine, Wisconsin, January 1998, at: http:/www.gdrc.org/u-gov/precaution-3.html.
} 


\subsection{Components of the precautionary principle}

Most formulations of the precautionary principle $^{21}$ adopt a three-part structure, which includes (a) the level of damage, specifying under which conditions the precautionary principle should be considered; (b) scientific criterion, specifying the status of knowledge according to the relationship between a given activity and a given effect; and (c) remedy, defining what decision makers should do in response to the given activity. ${ }^{22}$ The consideration of serious consequences to the environment, combined with uncertainty about the situations in which these consequences might materialise, creates a condition where precautions should be taken. In other words, precaution is found at the intersection of the risk of immense harm and uncertainty (Whiteside 2006).

\subsubsection{Damage}

The levels of damage are different in various international documents. Some of them require a low harm threshold, ${ }^{23}$ but others indicate that the degree of potential damage should be "serious and irreversible". ${ }^{24}$ According to the "serious" criterion, it seems that if the damage in question is less than serious, the precautionary principle may not be applied. However, it is uncertain at what stage damage would amount to "serious" damage, and it might depend on specific situations in each case and would require a threshold be established. ${ }^{25}$ Irreversible damage, compared with "serious" damage, might be easier to define; however, it does not provide specific guidance for practice. The vagueness of the level of damage gives critics some leverage against the principle as the precautionary principle "is deeply perverse in its implications for the environment and human welfare" (Cross 1996) and is a "marvellous piece of rhetoric" (Wildavsky 1995).

\subsubsection{Scientific criterion}

One of the few agreements between scientists and policy-makers about the health of the ecosphere is the importance of science in environmental policy. However, Marr

\footnotetext{
${ }^{21}$ For example:
}

- See supra note 6.

- The preamble of Convention on Biological Diversity reads: "[n]oting also that where there is a threat of significant reduction or loss of biological diversity, lack of full scientific certainty should not be used as a reason for postponing measures to avoid or minimize such a threat."

- See supra note 9.

- Article 3 paragraph 1 of London Protocol to the Convention on the Prevention of Pollution by Dumping of Wastes and other Matters reads: "[i]n implementing this Protocol, Contracting Parties shall apply a precautionary approach to environmental protection from dumping of wastes or other matter whereby appropriate preventative measures are taken when there is reason to believe that wastes or other matter introduced into the marine environment are likely to cause harm even when there is no conclusive evidence to prove a causal relation between inputs and their effects."

22 Manson, supra note 8, p. 265.

${ }^{23}$ Such as the OSPAR Convention, and the Helsinki Convention, see supra note 30.

${ }^{24}$ For example the Rio Declaration, and the Convention on Biological Diversity, see supra note 30.

${ }^{25}$ Atapattu, supra note 7, pp. 209-210. 
notes that all scientific information is developed in the face of uncertain risk, which stems from five sources and expresses divergent views presented by a large number of scientists. ${ }^{26}$ For example, on the one hand, the International Panel on Climate Change insists that global warming results from greenhouse gases discharged by human activities; on the other hand, some government leaders support the view that the warming trend is part of a natural process. ${ }^{27}$ The uncertainty often reflects inherent scientific limitations in extrapolating laboratory findings to the real world or in disentangling the many confounding factors involved in epidemiologic or ecologic studies. ${ }^{28}$ As a lack of concrete scientific evidence impedes the pace of efforts to combat problems such as climate change, ecosystem degradation and resources depletion, the precautionary principle tries to establish a bridge between scientific uncertainty and policy decision making in order to improve society's ability to identify and correct environmental and health problems (Kriebel et al. 2001).

Scientific uncertainty also raises the question of what level of damage must be evident before the precautionary principle will be applied. In other words, the task for decision makers is to determine what degree of uncertainty is acceptable in approving specific activities. The standard depends on many factors and varies from one environment to another. However, some authors have identified two levels of confidence as to when the precautionary principle should be used: a level of "reasonable scientific possibility" and a level of "reasonable scientific probability". 29 According to this classification, the former exists whenever the empirical scientific data, but not the hypotheses, provide a rational basis, even when the data are still being questioned among scientists; the latter exists whenever there is "general acceptance" in the science community, if not unanimity, then at least more than a minority opinion, of the available data and method, and a specific conclusion can be drawn from that data. It has been suggested that these two levels be further elaborated; specific situations might require their use separately or jointly in different international treaties. $^{30}$

For the sake of objectifying the precautionary principle, it is necessary to identify reasonable thresholds; therefore, risk evaluation methods, such as risk assessment methods, have to be utilised. ${ }^{31}$ Even though there is no recognised risk assessment method as yet, ${ }^{32}$ some successful examples of how risk assessment methods should

\footnotetext{
${ }^{26}$ These sources are: the variables chosen, the measurements made, the samples drawn, the models employed and the causal relationships inferred. See: Marr, supra note 17, p. 25; State, James E., and Walker, Vern, R., "Refining the Precautionary Principle in International Environmental LAW", (1995) 14 Virginia Environmental Law Journal 423, p. 448.

27 Atapattu, supra note 7, pp. 211-212.

${ }^{28}$ Goldstein, supra note 14.

${ }^{29}$ Hickey, James E and Walker, Vern R, "Refining the Precautionary principle in International Environmental Law”, (1994-1995) 14 Virginia Environmental Law Journal 423, p. 449.

${ }^{30}$ Ibid., p. 450. Hickey and Walker state that "an agreement might require a reasonable scientific 'probability' that the activity can produce the kind of adverse effect that is to be avoided, but only a reasonable scientific 'possibility' that the exposure contribution from the contemplated activity will produce the adverse effect."

${ }^{31}$ Marr, supra note 17, pp. 28-32; Atapattu, supra note 7, pp. 214-218.

${ }^{32}$ Krämer, Ludwig, "Evaluation of the EC Chemicals Law", in Winter, Gerd (Eds.), Risk Assessment and Risk Management of Toxic Chemicals in the European Community, (Nomos, 2000), pp.14-34, p. 22.
} 
look have been established by both national councils and international organisations. ${ }^{33}$ Risk assessment is a prudent method of anticipating a worst-possible effect for the environment in cases of uncertainty, and its four components could be summarised as: (1) identification of adverse effects; (2) quantisation of the adverse effects; (3) appraisal of exposure; and (4) conclusion of overall health risk based on previous steps. ${ }^{34}$ As for the controversial precautionary principle, risk assessment methods also trigger intensive debate, claiming that risk assessment is subjective at every stage (Slovic 1999). Therefore, it is necessary for decision makers to balance the level of uncertainty, possibility or probability of serious harm to human health and the environment on the one hand, and the interests involved in the activities in question on the other, during the decision-making process.

\subsubsection{Remedy}

The greatest importance of the precautionary principle is that positive activities to protect the environment have to be employed even before concrete scientific proof of potential harm has been provided. Thus, the essence of the principle lies in the timing of, rather than the need for, a remedy. ${ }^{35}$ Policy-makers have to impose mitigation remedies when the damage and knowledge conditions are met. However, they have to consider some limitations of the precautionary principle, such as the principle of proportionality and the principle of sustainability.

Proportionality principle The proportionality principle, as a general limitation for the precautionary principle, requires that the pace of taking positive action depends on the degree of potential adverse effect to the environment. ${ }^{36}$ If a given action has been prohibited because of scientific uncertainty, under which policy-makers have decided to take precautionary principle, the uncertainty has to be reviewed at regular intervals based on new scientific and technological development. ${ }^{37}$ Therefore, it is necessary for policy-makers to adopt a monitoring system in international treaties to adjust methods promptly, especially when an individual State limits imports based on the precautionary principle. ${ }^{38}$ Another element of the proportionality principle is the analysis of cost-effectiveness or social-economic considerations. ${ }^{39}$ For example, the UN Fish Stocks Agreement declares that in implementing the precautionary principle, states shall take environmental and socio-economic conditions into account $^{40}$; the OSPAR Convention and Helsinki Convention provide that when determining BAT, economic and technological considerations carry the same

\footnotetext{
33 The United States National Research Council and European Commission describe the Risk Assessment Method in detailed. See: Marr, supra note 17, pp. 28-29.

${ }^{34}$ Ibid., p. 29.

${ }^{35}$ Freestone, David, and Hey, Ellen, "Origins and Development of the Precautionary Principle", in Freestone and Hey (Eds.), The Precautionary Principle and International Law: The Challenge of Implementation, (Kluwer Law International, 1996), p. 13.

${ }^{36}$ Marr, supra note 17 , pp. 35-40.

${ }^{37}$ Wolfrum, supra note 12 , p. 208.

38 Ibid.

${ }^{39}$ Marr, supra note 17 , pp. $35-40$.

${ }^{40}$ Article 6, paragraph 3 (c) UN Fish Stocks Agreement, UN Doc. A/CONF.164/37.
} 
importance as the precautionary principle. ${ }^{41}$ Moreover, Principle 15 of the Rio Declaration also indicates that measures taken on the basis of the precautionary principle should be cost-effective and that States obey the principle only according to their capability. Thus, States with different economic and financial capabilities are under varying obligations to fulfil the precautionary principle. Although this economic consideration is not an independent component for other international treaties, there is growing support to consider it when applying precautionary principle. $^{42}$

The principle of sustainable development The relationship between the principle of sustainable development and the precautionary principle is quite complicated. On one hand, both of the two principles express the intention of protecting the environment, but to a varying degree. The principle of sustainable development permits the adoption of specific activities at a "sustainable" level, which means that what we do today cannot compromise the ability of future generations to satisfy their own needs. ${ }^{43}$ The precautionary principle, as a risk regulation instrument, prefers preventing potential damage to restoration. For potentially irreversible damage, both principles might require prevention, measures that under this situation, the precautionary principle serves as a way to establish thresholds for sustainable development. On the other hand, they also conflict with each other. ${ }^{44}$ For example, the complete prohibition of a given action, such as large-scale pelagic driftnets, collides with the principle of sustainable development, which tolerates that specific activity to a specific level. In practice, the conflict has been regulated through applying the precautionary principle to evaluate the level of sustainable use. The Draft Guidelines for the Ecological Sustainability of Non-Consumptive and Consumptive Uses of Wild Species provides that the precautionary principle is one of the preconditions for establishing whether the use of a wild species is sustainable or not. $^{45}$

\subsubsection{Burden of proof}

To deal with uncertainties, two general methods are used by law: evidentiary presumptions, which can bridge gaps in our knowledge, and the burden of proof, which can be employed to allocate the risk of uncertainty (Bodansky 1991). The precautionary principle, as a tool for facilitating potential harm to human health and environment, would require a shift in the burden of proof ${ }^{46}$ and require the party who intends to engage in the environmentally sensitive activity to prove that it will

\footnotetext{
${ }^{41}$ Appendix 1, paragraph 2 (b) and (c) OSPAR Convention; Regulation 3 paragraph 2 of Annex II of the Helsinki Convention.

${ }^{42}$ Marr, supra note 17 , pp. 39-40.

${ }^{43}$ Wolfrum, supra note 12 , p. 210.

${ }^{44}$ Marr, supra note 17, p. 41.

${ }^{45}$ Wolfrum, supra note 12 , p. 211.

46 The point of view is supported by most writes such as: Sand, supra note 1, p. 273; Marr, supra note 17, pp. 16-17; Hey, supra note 16, p.310. On the contrary, Atapattu argues that the precautionary principle does not actually reverses the burden of proof, see supra note 7, pp. 231-233.
} 
be harmless. In other words, those parties who wish to protect the environment do not need to prove that certain activities or substances are indeed harmful. The presumption behind the reversal of the burden of proof is that an activity is harmful to environment unless proven otherwise. ${ }^{47}$ In the absence of scientific evidence of long-term harmful impact, the precautionary principle might entail prohibition of a disputed activity until proven otherwise.

To take up the example of drift net fishing again, the burden of proof for the precautionary principle is expressed by a series of United Nations General Assembly (UNGA) Resolutions relating to the prohibition of large-scale pelagic driftnet fishing. As driftnet fishing has an adverse impact on marine living resources, the UNGA sets out a moratorium for this kind of fishing in its Resolution 44/225 of 22 December 1989. In the absence of scientific certainty concerning the precise adverse impact of driftnet fishing, the precautionary principle bans it totally unless "effective conservation and management measures be taken based upon statistically sound analysis to be jointly made by concerned parties of the international community with an interest in the fishery resources of the region, to prevent the unacceptable impact of such fishing practices on that region and to ensure the conservation of the living marine resources of that region". 48 It is the burden of states intending to exercise driftnet fishing to prove that the action will not lead to any deterioration in living marine resources. Although calling the "moratorium" a permanent prohibition is somewhat of an exaggeration, it does pose an extremely arduous challenge to dispel all possibilities of long-term adverse effects on driftnet fishing. Although the Resolution is not binding, it has been supported by a few international instruments, ${ }^{49}$ and has been reaffirmed several times by following General Assembly Resolutions. ${ }^{50}$

Another example can be found in Council Regulation 345/92 of the European Economic Community:

A derogation shall be granted until 31 December 1993 to vessels that have fished for long finned albacore tuna with driftnets.... This derogation shall expire on the above mentioned date, unless the Council, acting by a qualified

\footnotetext{
${ }^{47}$ Wolfrum, supra note 12, p. 209; Garcia, Serge, "The Precautionary Approach to Fisheries and Its Implications for Fishery Research, Technology and Management: An Updated Review", in FAO Fisheries Technical Papers 350/2 (FAO, 1996) 1, p.21; González-Laxe, Fernando, "The Precautionary Principle in Fisheries Management", (2005) 29 Marine Policy 495, p.496.

${ }^{48}$ United Nations General Assembly Resolution 44/225 of 22 December 1989, Article 4 (a).

49 In July 1990, the International Whaling Commission adopted the Resolution in Support of the United Nations General Assembly Initiative Regarding Large-Scale Pelagic Driftnet Fishing and its Impact on the Living Marine Resources of the World's Oceans and Seas”. On 31 July - 1 August 1990 the heads of government of the South Pacific Forum Nations reaffirmed their opposition to large-scale pelagic driftnetting and endorsed the Wellington Convention. In September 1990, the Fisheries Commission of the Organization for Economic Co-operation and Development (OECD) supported the implementation of the U.N. resolution. On 31 October 1990 the South Pacific Conference adopted a resolution condemning driftnet fishing in the South Pacific region. More information see: http://www.earthtrust.org/dnpaper/ intllaw.html

50 The Resolution 44/225 was reaffirmed by the UNGA Resolution 45/197 in December 1990; the UNGA Resolution 46/215 In December 1991; UNGA Decisions 47/443 of 22 December 1992, 48/445 of 21 December 1993 and 49/436 of 19 December 1994; and UNGA Resolution 51/36 which was adopted on 21 January 1997.
} 
majority on a proposal from the Commission, decides to extend it in the light of scientific evidence showing the absence of any ecological risk linked thereto. ${ }^{51}$

However, the precautionary principle does not put an unreasonable or impossible burden of proof onto the party or innovator, but relieves the rest of society from this obligation. The level of proof required is that a given activity is demonstrated to be safe, beyond reasonable doubt. Requiring an absolute demonstration may be an impossible requirement that may impair technological and economical development. ${ }^{52}$

\section{The precautionary principle in operation}

The precautionary principle has become a reference rule for international treaties, courts and tribunals. It has been adopted by a number of international documents on pollution of the marine environment, ${ }^{53}$ marine biodiversity, ${ }^{54}$ controlling dumping and incineration, ${ }^{55}$ transboundary movements of radioactive and hazardous substances, ${ }^{56}$ and the conservation of marine living resources. ${ }^{57}$ Of these international documents, this article focuses on analysing fishery treaties, as these treaties explicitly state the precautionary principle, especially the UN Fish Stocks Agreement, which demonstrates that the fundamental position of the precautionary principle and has been widely accepted. Additionally, cases concerning the precautionary principle have appeared before international courts and tribunals, including the International Court of Justice, the International Tribunal for the Law of the Sea, the WTO Appellate Body, and the European Court of Human Rights. Especially some cases in the fisheries context have drawn international attention. Thus, the following section will lay out how the precautionary principle is applied to international fishery treaties and how it is addressed by international courts and tribunals.

\subsection{Precautionary principle in fisheries management}

As a worldwide trend towards concern for the management of fisheries, and based on the modern requirement to deal explicitly with uncertainty, the precautionary principle, as one of the international level principles for nature conservation, has been progressively forced onto fisheries' systems in order to reduce risk to resources

\footnotetext{
$\overline{51}$ Council Regulation 345/92 of the European Economic Community, 1992, Article 9(a).

52 Saunders, Peter T., "Use and Abuse of the Precautionary Principle", at http://www.i-sis.org.uk/prec.php

53 Article 2(a) and 5(a) of The 1992 Convention on the Protection of Transboundary Watercourses and International Lakes; Article 5 of 1999 Protocol on Water and Health to the 1992 Convention on the Protection and Use of Transboundary Watercourses and International Lakes; the preamble and Article 1 of the Stockholm Convention on Persistent Organic Pollutants.

54 The preamble and Article 8 (a), (b) and (c) of the 1992 Convention on Biological Diversity.

55 The OPSAR Convention and Helsinki Convention.

${ }^{56}$ Article 8 (3) of Protocol on the Prevention of Pollution of the Mediterranean Sea by Transboundary Movements of Hazardous Wastes.

57 Article II (4) of the Agreement on the Conservation of Cetaceans of the Black Sea, Mediterranean Sea and Contiguous Atlantic Sea.
} 
and the environment. From the 1982 United Nations Convention for the Law of the Sea (hereafter UNCLOS), the precautionary principle provides "flesh on the bone" for the UNCLOS provisions relating to the conservation of stocks, even though it is not directly included in the wording of the UNCLOS which refers to uncertainty relating to the concept of "best scientific evidence". "Further implementation of the precautionary principle happened in the 1993 session of UN Fish Stocks Conference, which required the Food and Agriculture Organization of the United Nations (FAO) to prepare a background paper on the precautionary principle to fisheries. In 1995, the precautionary principle was finally conceptualised in an important international fishery treaty-the Fish Stocks Agreement, which entered into force on 11 December 2001.

\subsubsection{The 1995 UN Fish Stocks Agreement}

The FAO in its 1995 report on the state of the world's fisheries stated that, at the beginning of the $1990 \mathrm{~s}$, " $69 \%$ of the world's marine fish stocks [...] are either fully to heavily exploited, overexploited, depleted" (Food and Agriculture Organization of the United Nations 1995). In addition, as $90 \%$ of the harvests of marine fishery resources would be encompassed by the coastal State 200 nautical miles EEZ (Lauck et al. 1998), States are obligated to take measures to ensure the effective conservation and management of straddling fish stocks and highly migratory fish stocks. The purpose of the 1995 UN Fish Stocks Agreement is to facilitate the implementation of certain provisions of the 1982 UNCLOS concerning the conservation and management of straddling fish stocks and highly migratory fish stocks. The Agreement complements the 1993 FAO Agreement to Promote Compliance with International Conservation and Management Measures by Fishing Vessels on the High Seas and the 1995 FAO Code of Conduct for Responsible Fisheries.

Article 6 of the Agreement calls upon States to apply the precautionary principle to conservation, management and exploitation of straddling fish stocks and highly migratory fish stocks in order to protect the living marine resources and preserve the marine environment. ${ }^{59}$ Where information is uncertain, unreliable or inadequate, States are required to be more cautious still. Even if there is an absence of adequate scientific information, this shall not be used as a reason for postponing or failing to take conservation and management measures. ${ }^{60}$

Precautionary reference points The Agreement not only requires the application of the precautionary principle to fishery management but also requires that States shall determine stock-specific reference points and to take action if they are exceeded. The details of the reference points are regulated in Annex II of the Agreement. A precautionary reference point is an estimated value derived through an agreed scientific procedure, which corresponds to the state of the resource and of the

\footnotetext{
${ }^{58}$ Marr, supra note 17 , p. 136.

${ }^{59}$ Article 6(1), supra note 54

${ }^{60}$ Ibid., Article 6(2).
} 
fishery, and which can be used as a guide for fisheries management. ${ }^{61}$ The Annex provides two types of precautionary reference points ${ }^{62}$ : conservation, or limit, reference points and management, or target, reference points.

Limit reference points ${ }^{63}$ set boundaries which are intended to constrain harvesting within safe biological limits, within which the stocks can produce maximum sustainable yield. Fishery management strategies should ensure that the risk of exceeding limit reference points is very low. If stock falls below a limit reference point or is at risk of falling below this reference point, conservation and management action should be initiated to facilitate stock recovery. A minimum standard for limit reference points is the fishing mortality rate, which generates maximum sustainable yield. $^{64}$ Target reference points ${ }^{65}$ are intended to meet management objectives. Fishery management strategies should ensure that target reference points are not exceeded on average.

When estimating the precautionary reference points, some relative elements of fish stocks have to be considered, such as the reproductive capacity, the resilience of each individual stock, and the characteristics of the fisheries exploiting the stock as well as other sources of mortality and major sources of uncertainty. ${ }^{66}$ However, limitations to data, models and paradigm are unavoidable in fishery science, especially given the movable and interconnected nature of fishery resources, ${ }^{67}$ it is possible that information for determining reference points for a fishery is poor or absent. Therefore, Annex II provides provisional reference points, which may be established by analogy to similar and better-known stocks. ${ }^{68}$ If so, the fishery shall be subject to enhanced monitoring so as to enable revision of provisional reference points as improved information becomes available.

Moreover, for stocks which are not overfished, fishery management strategies shall ensure that fishing mortality does not exceed limit reference points which corresponds to maximum sustainable yield and that the biomass does not fall below a predefined threshold. For overfished stocks, a target could be the biomass which would produce maximum sustainable yield. ${ }^{69}$

Application of the precautionary approach ${ }^{70}$ The application range of the precautionary approach is regulated in Article 3 of the Agreement. It claims that the Agreement applies to conservation and management in areas beyond national jurisdiction. However, it makes exceptions for the precautionary principle and the conservation and management measures which "apply also to the conservation and management of such stocks within areas under national jurisdiction, subject to the

\footnotetext{
${ }^{61}$ Ibid., Annex II Article 1.

${ }^{62}$ Ibid., Annex II Article 2.

${ }^{63}$ Ibid., Annex II Article 2 and Article 5.

${ }^{64}$ Ibid., Annex II Article 7.

${ }^{65}$ Ibid., Annex II Article 2 and Article 5.

${ }^{66}$ Ibid., Article 6(3).

${ }^{67}$ Garcia, supra note 62, p.10.

${ }^{68}$ Supra note 54, Article 6(6).

${ }^{69}$ Ibid., Annex II Article 7.

${ }^{70}$ Article 6 of the UN Fish Stock Agreement uses the term "precautionary approach" instead of "precautionary Principle". In order to correspond with the Agreement, under this subtitle, this article will use "precautionary approach".
} 
different legal regimes that apply within areas under national jurisdiction and in areas beyond national jurisdiction as provided for in the (the Law of the Sea) Convention". ${ }^{71}$ It is an obligation for coastal States to adopt the precautionary approach within the areas under their jurisdiction. ${ }^{72}$ Since it is not easy for the international society to develop unanimous measures or standards to apply the precautionary approach to manage fishery resources within areas under their jurisdiction, the Agreement allows States to apply mutatis mutandis in areas under their jurisdiction. ${ }^{73}$

However, the Agreement also provides some general rules when States implement the precautionary approach. States should improve decision making by obtaining and sharing the best scientific information available and implementing improved techniques for dealing with risk and uncertainty; shall apply guidelines in Annex II; shall take into account uncertainties relating to the size and productivity of the stocks, reference points, stock condition in relation to such reference points, levels and distribution of fishing mortality and the impact of fishing activities on non-target and associated or dependent species, as well as existing and predicted oceanic, environmental and socio-economic conditions; and should develop data collection and research programmes to assess the impact of fishing on non-target and associated or dependent species and their environment in implementing the precautionary approach. ${ }^{74}$

Once reference points are developed, or close to being developed, States have an obligation to keep their fishing under these limits. If they are exceeded, States must, without delay, take the action given in Annex II. ${ }^{75}$ Moreover, States have to monitor the status of target stocks or non-target or associated or dependent species in order to review their status and the efficacy of conservation and management measures and to revise those measures regularly in the light of new information. ${ }^{76}$ For new or exploratory fisheries, States shall not employ unlimited exploitation, but remain in control until conservation and management measures, based on assessment of the impact of the fisheries on the long-term sustainability, can be implemented. ${ }^{77}$ For some special situations, where a natural phenomenon has had a significant adverse impact on the status of fish stocks, States shall adopt emergency measures to ensure that fishing activities do not exacerbate this adverse impact. ${ }^{78}$

\subsubsection{The 1995 UN Fish Stocks Agreement and the UNCLOS}

Article 4 of the Agreement expresses the relationship between the Agreement and the UNCLOS, as:

Nothing in this Agreement shall prejudice the rights, jurisdiction and duties of States under the Convention. This Agreement shall be interpreted and applied in the context of and in a manner consistent with the Convention.

\footnotetext{
${ }^{1}$ Ibid., Article 3(1).

${ }^{72}$ Marr, supra note 17, p. 142.

${ }^{73}$ Ibid., Article 3(2).

${ }^{74}$ Ibid., Article 6(3).

${ }^{75}$ Ibid., Article 6(4).

${ }^{76}$ Ibid., Article 6(5).

${ }^{77}$ Ibid., Article 6(6).

${ }^{78}$ Ibid., Article 6(7).
} 
Although the UNCLOS does not use the precautionary principle explicitly, the obligation to apply the principle to fisheries is "compatible with the UNCLOS". 79 It is clear that States have a duty to adopt measures for conservation of the living resources of EEZ and the high seas. ${ }^{80}$ The UNCLOS especially regulates obligations for States to conserve and manage straddling fish stocks ${ }^{81}$ and highly migratory fish stocks $^{82}$ in EEZ. The Agreement seeks to provide more effective and specific enforcement of the conservation and management measures adopted for such stocks for flag States, port States and coastal States. To some extent, the Agreement, adopting the precautionary principle in fisheries, represents a development for the UNCLOS both in theory and practice.

\subsection{Application of the precautionary principle in cases}

Since 1995, the Nuclear Test Case filed before the International Court of Justice (ICJ), and a few cases relating to the precautionary principle have been submitted to various international bodies, such as the International Tribunal for the Law of the Sea (ITLOS), ${ }^{83}$ the WTO Appellate Body, ${ }^{84}$ the European Court of Justice, ${ }^{85}$ and the European Court of Human Rights. ${ }^{86}$ These cases reflect the process of acceptance of the precautionary principle in international society.

\subsubsection{The nuclear test case}

On 13 June 1995, the French President declared a decision about a final series of eight nuclear weapon tests in the South Pacific starting in September 1995. The government of New Zealand requested the ICJ to examine the situation pursuant to paragraph 63 of the 1974 Judgment of Nuclear Test Case (1973), which reads:

Once the Court has found that a State has entered into a commitment concerning its future conduct it is not the Court's function to contemplate that it will not comply with it. However, the Court observes that if the basis of this Judgment were to be affected, the Applicant could request an examination of the situation in accordance with the provisions of the Statute; the denunciation by France, by letter dated 2 January 1974, of the General Act for the Pacific Settlement of International Disputes, which is relied on as a basis of jurisdiction in the present case, cannot constitute by itself - obstacle to the presentation of such a request.

\footnotetext{
${ }^{79}$ Marr, supra note 17, p.145.

${ }^{80}$ Article 61, 117 and 119, UNCLOS.

${ }^{81}$ Article 63, UNCLOS.

${ }^{82}$ Article 64, UNCLOS.

${ }^{83}$ The Southern Bluefin Tuna cases, at http://www.itlos.org/cgi-bin/cases/case_detail.pl?id=3\&lang=en and MOX Plant case, at: http://www.itlos.org/cgi-bin/cases/case_detail.pl?id=10\&lang=en

${ }^{84}$ Beef-Hormone case, at http://www.wto.org/english/tratop_e/sps_e/sps_agreement_cbt_e/c5s $3 p 1$ e.htm

${ }^{85}$ Anklagemyndigheden v. Ditlev Bluhme (Danish Bees case), Case C-67/97, 1998, Recueil, 1998-I, p. 8033 .

${ }^{86}$ Balmer-Schafroth and Others v. Switzerland, (67\1996\686\876), Reports of Judgments and Decisions 1997-IV.
} 
New Zealand, in this case, intended to protect its rights through two requirements: (1) France refrain from performing any further nuclear tests; and (2) France undertake an Environmental Impact Assessment in accordance with generally accepted international standards. New Zealand believed that it was a clear obligation upon France to conduct an Environmental Impact Assessment which flowed from a specific treaty, i.e. the Noumea Convention, and from customary international law, before carrying out any further nuclear tests. In addition, New Zealand was convinced that France was acting illegally, as its conduct would cause the introduction of radioactive material into the marine environment. Furthermore, New Zealand claimed that the precautionary principle, as a widely accepted and operative principle of international law, has the effect that in situations that may possibly be significantly environmentally threatening, the burden is placed upon the party seeking to carry out the conduct to prove that that conduct will not lead to such a threat. ${ }^{87}$

On the other hand, France argued in its defence that the status of the precautionary principle in international law was not certain and that the burden of proof should be different in the environmental field than any other area of international law. ${ }^{88}$

The Court mainly focused on one question: Did the requests submitted to the Court by New Zealand fall within the provisions of paragraph 63 of the 1974 Judgment? In the Court's opinion, the question had two elements. The first element concerned the procedure envisaged by the court in paragraph 63, where it states that the applicant could request an examination of the situation in accordance with the provisions of the Statute. The second element concerned the question as to whether the "basis" of that Judgment had been "affected". Finally, the Court found that the first element was satisfied, which meant a special procedure could be adopted for access to it. However, there was no case affecting the basis of the 1974 Judgment, as the basis of that judgment was France's undertaking not to conduct any further nuclear atmospheric testing and only a resumption of nuclear tests in the atmosphere would therefore have affected it. Therefore, the Court concluded that New Zealand's requirement "does not fall within the provisions of the said paragraph 63 and must consequently be dismissed". 89

Although the Court did not refer to substantial arguments between these two parties, Judge Weeramantry clearly expressed his dissent on the precautionary principle. He indicated that the precautionary principle functions to protect the environment as it deals with evidentiary difficulty, and the principle "is gaining increasing support as part of the international law of the environment". $90 \mathrm{He}$ also referred to the Bergen Ministerial Declaration of 1990 as well as several environmental treaties involving the principle and noted that the precautionary principle is "a principle of relevance to New Zealand in its application to this Court and one which inevitably calls for consideration in the context of this case." 91

\footnotetext{
${ }^{87}$ For more details, see http://www.icj-cij.org/docket/files/97/7187.pdf

${ }^{88} \mathrm{ICJ}, \mathrm{CR} / 95 / 20$, p. $71-72$ and 75.

${ }^{89}$ ICJ, No. 95/29, 22 September 1995, at: http:/www.icj-cij.org/docket/files/97/3417.pdf

90 See: ICJ Reports 1995, p. 342, at: http://www.icj-cij.org/docket/files/97/7567.pdf

91 Ibid., p. 343
} 
Moreover, he claimed that the precautionary principle, embodied in the Maastricht Treaty, which formed the basis of European Community policy on the environment, would lead one to expect that the principle, thus applicable to Europe, would also apply to European activity in other global theatres. ${ }^{92}$

Judge Palmer also expressed a high level of support for the precautionary principle in his dissent. He regarded the principle as "a principle of customary international law relating to the environment" and insisted that "there are obligations based on Conventions that may be applicable here requiring environmental impact assessment and the precautionary principle to be observed" (ICJ Reports 1995).

It was a pity that the Court missed such an important opportunity to contribute to the most critical issue of international environmental law, particularly relating to nuclear tests, which might cause serious and irreversible damage to human health and the environment. ${ }^{93}$ However, these dicta expressed that a trend for demanding the assessment of new principles in international environmental law, especially the precautionary principle, had been emerging. Moreover, the similar affirmative evaluations by Judges predict further acceptance of the principle in cases later on.

\subsubsection{The Southern Bluefin Tuna Cases}

The southern bluefin tuna is a highly migratory fish species which traverses the EEZ and territorial sea of several countries and the high seas, including the Southern Ocean. Australia and New Zealand argued that as Japan's actions amounted to a failure to conserve and to cooperate in the conservation of the species, it was significantly overfished and below commonly accepted thresholds for biologically safe parental biomass. They also claimed that Japan, by initiating a unilateral experimental fishing programme for the southern bluefin tuna in 1998 and 1999, threatened serious or irreversible damage to the southern bluefin tuna population. Therefore, Australia and New Zealand filed requests for a prescription of provisional measures (interim injunction) against Japan in front of the ITLOS in 1999. The merits of the cases concern the conservation of the population of the southern bluefin tuna.

The Applicants requested that Japan immediately ceases its fishing of the southern bluefin tuna and restricts its catch to its national quota as last agreed; that the parties act consistently with the precautionary principle in fishing for the species pending final settlement of the dispute; and that the parties keep status quo until they had a final decision.

Japan challenged the jurisdiction of the Tribunal and denied that the provisional measures were appropriate. It claimed that to cease experimental fishing in 1999 would not have any sustainable effect on the southern bluefin tuna stock. On the contrary, it could cause irreparable damage to scientific research. Moreover, it also contended that there was no urgency in the request of the Applicants. Therefore, the Tribunal should reject the provisional measures requested by Australia and New Zealand. It also contained a counter request by Japan for provisional measures.

\footnotetext{
92 Ibid., p. 344.

93 Ibid., p. 420.
} 
The Tribunal noted that:

There is not disagreement between the parties that the stock of Southern Bluefin Tuna is severely depleted. It considered that there is scientific uncertainty regarding measures to be taken to conserve the stock. ...[i]n the circumstances the parties should act with prudence and caution to ensure that effective conservation measures are taken to prevent serious harm to the stock of Southern Bluefin Tuna. The Tribunal ordered inter alia that the parties should resume negotiations without delay with a view to reaching agreement on measures for the conservation and management of Southern Bluefin Tuna and that the parties should restrict their catches. (Southern Bluefin Tuna Cases 1999)

The Tribunal did not mention the precautionary principle specifically, merely referring to a need for parties to "act with prudence and caution" when there is "scientific uncertainty". Nevertheless, the spirit of the principle had been explicitly presented and adopted by the Tribunal.

Judge Laing emphasised that even though the application of precautionary notions remained open to interpretation, it was a reality that it had been broadly accepted. ${ }^{94}$ However, it was too early to say that the precautionary principle had been a principle of customary international law. ${ }^{95}$ Indeed, the Judge agreed that the precautionary principle could be adopted as a flexible "approach", rather than a principle, to prevent serious environment damage. ${ }^{96}$

Judge Treves also expressed his regret at the absence of an explicit confirmation of the precautionary principle in the Tribunal's Order. As the status of the principle was still unclear and it was hard to say that the principle was a binding principle, he also agreed that it was not necessary to recognise the principle is a rule of customary international law. However, in his view, it could be treated as a logical consequence of provisional measures. In other words, provisional measures require prevention of serious damage, even though the actual occurrence of damage is uncertain. ${ }^{97}$

Moreover, Ad Hoc Judge Shearer indicated that the Tribunal's measures were rightly based upon considerations deriving from a precautionary principle, although the Tribunal did not open the discussion of the principle. ${ }^{98}$

In summary, in the Southern Bluefin Tuna case, the precautionary principle was clearly adopted by the Tribunal, ${ }^{99}$ and the role of the principle, to prevent serious damage of the marine environment, was highlighted by the cases in spite of the lack of explicit reference. It is beyond doubt that the precautionary principle has been accepted by international practices to prevent serious damage to the environment, even if certain scientific evidence of such kind of damage is not available.

\footnotetext{
94 Separate opinion, Judge Laing, paragraph 15, at: http://www.itlos.org/start2_en.html

95 Ibid., paragraph 16.

96 Ibid., paragraph 19.

${ }^{97}$ Separate opinion, Judge Treves, paragraph 9. http://www.itlos.org/start2_en.html

98 Separate opinion of Judge Shearer, paragraph, p. 6. at: http://www.itlos.org/start2_en.html

99 Sands, supra note 1, pp. 276-277.
} 


\section{A rule of customary international law?}

Whether the precautionary principle has already become a rule of customary international law is still an unsolved question. The Statute of the International Court of Justice defines the "customary international law" as "international custom, as evidence of a general practice accepted as law". The elements of customary international law include (a) duration, (b) uniformity and consistency of the practice, (c) generality of the practice, and (d) opinion juris (Brownlie 2003).

Scholars who support the idea of the precautionary principle as a customary international law do provide some arguments. Firstly, the principle has been adopted by many international treaties, which can, under certain situations, be considered an authority for proving the existence of obligations of customary law (Freestone 1991). Secondly, there are a number of decisions handed down by international courts and international tribunals, which can be considered as primary evidence of States' practices, supporting and adopting the principle. Thirdly, more and more national laws implement the principle and national courts adopted it into judgments. Based on the above reasons, the patrons insist that the precautionary approach, through more than a 20-year evolution, has become or at least approached the status of a principle of customary international law (Handl 1990; Gündling 1990). ${ }^{100}$

On the other hand, some critics can also list some bases for rejecting the precautionary principle. The most well known is that the principle is too vague to be acknowledged by all governments regardless of how well they protect the environment (Jordan et al. 1999). Moreover, it is not clear to critics whether it is a "principle" or an "approach". If the Rio Declaration could be deemed as the embodiment of the principle, it advocates a precautionary approach as the opposite to a precautionary principle. It means that the precaution should not be regarded as legal rule, but rather a method. Furthermore, the principle has been incorporated into national laws; therefore, it is difficult to prove that uniformity and consistency of practices exist. ${ }^{101}$ Therefore, at the present time, the status of the principle remains rather uncertain.

It is still too early to identify the customary international law status of the precautionary principle. The significant development of the principle cannot be ignored by international society. It is beyond doubt that the principle has greatly influenced decision-making progress at both international and national level. However, it is also true that there are still some gaps and flaws in the principle which need to be improved. A widely accepted definition of the principle should be drawn formally by the international community as soon as possible. The "approach"

\footnotetext{
${ }^{100}$ Sand, supra note 1, p.279; Cameron and Abouchar, supra note 2, pp.19-21; Marr, supra note 17, pp. 202-225; Nollkaemper, supra note 15, p.107; de La Fayette, Louise, Book Review, (1991) 38 Netherland's International Law Review 73, p. 76; Freestone, David, "The Precautionary Principle", in Churchill, R. R and Freestone, David (Eds.), International Law and Global Climate Change, 1991, pp3638; Gündling, Lothar, "The Status in International Law of the Principle of Precautionary Action", in Special Issue, The North Sea: Perspectives on Regional Environmental Cooperation, 5 International Journal Estuarine \& Coastal Law 23, (1990), pp. 27-30; Handl, Günther, "Environmental Security and Global Change: The Challenge to International Law", 1 Yearbook International Environmental Law 3, (1990), pp. 22-24.

101 Atapattu, supra note 7, p. 284.
} 
and "principle" problem may be addressed by more State practices. Moreover, general and consistent practices must be developed as further cases are submitted to international and national courts. The precautionary principle is on its way to becoming a customary international law. Ultimately, time will evaluate the principle and provide a final answer at a later stage.

\section{Conclusion}

Damage to the marine environment, marine biodiversity and living marine resources are often long-term, and the disastrous effects always persist beyond the human activity that caused them. Therefore, what we have damaged in the sea area will deplete the rights of future generations to utilise the oceans. The precautionary principle calls for early prevention, to avoid and relieve uncertain serious and irreversible damage to marine ecosystems, and has come to the fore in decision-making processes since the principle was first adopted in national laws in the 1970s. More than 10 years later, the precautionary principle was adopted in the Rio Declaration and widely accepted by the international community. Since then, the principle has been involved in more and more international instruments.

Although there is no uniform definition of the precautionary principle so far, four elements of the principle can be identified, namely the level of damage, scientific criterion, remedy, and burden of proof. The principle deals with the problem of how to make a decision when there is a lack of complete scientific information regarding serious damage. The first three elements vary from one environment to another. Decision makers have to consider some limitations, such as the proportionality principle and the principle of sustainable development, when they employ the precautionary principle. Moreover, the principle dictates that it is the burden for those parties who wish to implement relevant activities to prove that certain activities or substances are indeed harmless.

The global natural environment, and particularly marine living resources, is facing growing pressure as the world's population and demand are gradually increasing. Therefore, in order to preserve the marine environment, its ecosystems and biodiversity, the precautionary principle has been implemented in a number of fishery treaties, among which the 1995 UN Fish Stocks Agreement is a good example. The Agreement could be considered for the development of the UNCLOS in the area of fishing and fishery resource conservation.

The precautionary principle has not only been adopted in international treaties but also in some cases by different international courts and tribunals. The Nuclear Test Case was the first one related to the principle submitted in front of the ICJ. Even though the Court did not exploit the opportunity to inquire into substantial questions in this case, some Judges expressed their support for the precautionary principle in their dissents. In the Southern Bluefin Tuna Cases, the Tribunal finally implemented the precautionary method; however, it did not mention the exact nature of the term "precaution". Even so, the case played a critical role in the evolution of the precautionary principle. It proved that the principle was formally accepted by international judicial practice. 
Whether the precautionary principle has become a rule of customary international law is still unclear. Solving this question is an important test for the development of the UNCLOS in the future. Neither the success of the principle, in theory or in practice, nor the flaws of the principle can be denied. As Judge Stein said: "One thing is clear-the precautionary principle will not go away. It is here to stay" (Stein et al. 1999).

\section{References}

Atapattu SA (2006) Emerging principles of international environmental law. Transnational Publishers, New York

Bodansky D (1991) New developments in international environmental law-remarks by Daniel Bodansky. Am Soc Int Law Proc 85:413-417

Brownlie I (2003) Principles of public international law, 6th edn. Oxford, New York

Burke W (1993) UNCED and the oceans. Mar Pol 17(6):519-533

Cross FB (1996) Paradoxical perils of the precautionary principle. Wash \& Lee L Rev 53:851-921

de La Fayette L (1999) The OSPAR Convention comes into force: continuity and progress. Int J Mar Coast Law 14(2):247-297

Food and Agriculture Organization of the United Nations (1995) The state of world fisheries and aquaculture. FAO Fisheries Department, Rome

Freestone D (1991) The precautionary principle. In: Churchill RR, Freestone D (eds.) International law and global climate change

Garcia S (1994) The precautionary principle: its implications in capture fisheries management. Ocean Coast Manag 22:99-125

Gündling L (1990) The status in international law of the principle of precautionary action. In: Freestone D, Ijlstra T (eds) Special Issue, The North Sea: perspectives on regional environmental cooperation. Int J Estuar Coast Law 5:23-30

Handl G (1990) Environmental security and global change: the challenge to international law. $1 \mathrm{Yb}$ Int'l Envtl L 3:22-24

Hewison G (1996) The precautionary approach to fisheries management: an environmental perspective. Int J Mar Coast Law 11(3):301-332

Hey E (1992) The precautionary concept in environmental policy and law: institutionalizing caution. Georgetown Int Environ Law Rev 4:303-305

Hey E, IJIstra T, Nollkaemper A (1993) The 1992 Paris Convention for the Protection of the Marine Environment of the North-East Atlantic: a critical analysis. Int J Mar Coast Law 18(1):12-13

Jordan A, O'Riordan T (1999) The precautionary principle in contemporary environmental policy and politics. In: Raffensberger C, Tickner J (eds.) Protecting public health and the environment: implementing the precautionary principle. Island Press, pp. 15-35

Kriebel D, Tickner J, Epstein P et al (2001) The precautionary principle in environmental science. Environ Health Perspect 109:871-876

Lauck T, Clark CW, Mangel B et al (1998) Implementing the precautionary principle in fisheries management through marine reserves. Ecol Appl 8(1):S72-S78

Manson NA (2002) Formulating the precautionary principle. Environ Ethics 24:263-264

Marr S (2003) The precautionary principle in the law of the sea-modern decision making in international law. Martinus Nijhoff, Den Haag/London

Nollkaemper A (1991) The precautionary principle in international environmental law: what's new under the sun? Mar Pollut Bull 22(2):107-110

ICJ Reports (1995) http://www.icj-cij.org/docket/files/97/7571.pdf

Sands P (2003) Principles of international environment law, 2nd edn. Cambridge University Press, New York

Slovic P (1999) Trust, emotion, sex, politics and science: surveying the risk assessment battlefield. Risk Anal 19(4):689-701

Southern Bluefin Tuna Cases (1999) No. 3 and 4 cases. International Tribunal for the Law of the Sea, Press 28, p. 1. http://www.itlos.org/news/press_release/1999/press_release_28_en.pdf 
Stein, Paul L (1999) Are decision-makers too cautious with the precautionary principle. Land and Environment Court of New South Wales Annual Conference Peppers Hydro Majestic, Medlow Bath, Blue Mountains, October 14-15, 1999. http://www.lawlink.nsw.gov.au/lawlink/supreme_court/1l_sc. nsf/pages/SCO_speech_stein_141099

Whiteside KH (2006) Precautionary politics: principle and practice in confronting environment risk. MIT Press, Cambridge.

Wildavsky A (1995) But is it true? A citizen's guide to environment health and safety issue. Harvard University Press, Cambridge 